\title{
Analysis of Settlements Patterns in Hatay Province
}

*

\author{
Zehra Tugba Guzel ${ }^{1}$ \\ ORCID: 0000-0002-6450-8204
}

\begin{abstract}
The settlement patterns that occur by the spatial distribution of the population vary according to the morphological characteristics and economic resources of the region at which they are located. While Hatay is located in Turkey's south between the Mediterranean Sea, the Amanos Mountains, and the Syrian border, it forms from settlements areas in which are diverse sizes and different shapes. The study aims to examine the impact of geomorphology on settlements and to reveal the relationship between the settlement typologies, economy, and demography. 2018 Corine Land Cover data, 2019 TUIK data, and Hatay Metropolitan Municipality data were investigated within this scope. According to the results, settlement areas of Hatay were classified into four groups with four patterns, while the patterns varied by the existence of economic structure. The pattern distribution was determined as dispersed-clustered in the industrial region, as linear in the tourism zone, and as dispersed in the agricultural production zone. Settlements were also densely affected and transformed by the 2011 Syrian refugee crisis due to the Syrian civil war. In conclusion, while geomorphology, advanced production systems, developed transportation axes, and international relations are effective in Hatay's settlement alterations, so these dynamics should strictly consider in city planning.
\end{abstract}

Keywords: Settlement patterns, geomorphological characteristics, economic structure, Syrian war, population change.

\footnotetext{
${ }^{1}$ Res Assist. Iskenderun Technical University, E-mail: ztugba.guzel@iste.edu.tr

idealkent @ C Kent Araştırmaları Dergisi (Journal of Urban Studies)

http://idealkentdergisi.com

Geliş Tarihi Received Date: 06.07.2021 Kabul Tarihi Accepted Date: 14.12.2021
} 


\title{
Hatay İlindeki Yerleşim Desenlerinin Analizi
}

\author{
Zehra Tuğba Güzel ${ }^{2}$ \\ ORCID: 0000-0002-6450-8204
}

\section{Öz}

Nüfusun arazi üzerindeki mekânsal dağılımına bağlı olarak meydana gelen yerleşim desenleri, bulundukları bölgenin morfolojik özelliklerine ve ekonomik kaynaklarına göre değiş̧iklik göstermektedir. Hatay, Türkiye'nin en güneyinde Akdeniz, Amanos Dağları ve Suriye sınırı arasında yer alırken, farklı büyüklük ve şekillerdeki yerleşim alanlarından oluşmaktadır. Çalışma, jeomorfolojinin yerleşimler üzerindeki etkisini incelemeyi ve yerleşim tipolojileri, ekonomi, demografi arasındaki ilişkiyi ortaya koymayı amaçlamaktadır. 2018 Corine Arazi Örtüsü verileri, 2019 TUIKK verileri ve Hatay Büyükşehir Belediyesine ait verileri çalışma kapsamında incelemiştir. Gözlemlenen sonuçlara göre, Hatay'ın kentin ekonomik çeşitliliğine göre yerleşim alanları doğrusal, kümelenmiş, dă̆ınık ve dağınık kümelenmiş desenlerin oluşmasını sağlamıştır. Sanayi bölgesinde dağınık-kümelenmiş, turizm bölgesinde doğrusal, tarımsal üretim bölgesinde dağınık olarak ayrılan yerleşim alanları, 2011 yılında başlayan Suriye savaşı nedeniyle Suriye göçünden de yoğun olarak etkilenmiş ve dönüşmüştür. Sonuç olarak, Hatay'ın yerleşim değiş̧imlerinde jeomorfoloji, gelişmiş üretim sistemleri, gelişmiş ulaşım aksları ve uluslararası ilişkiler etkili olduğu belirlenmiştir. Belirlenen bu dinamiklerin şehir planlamasının gelecek previzyonunda kesinlikle dikkate alınması gereken başliklardır.

Anahtar Kelimeler: Yerleşim şekilleri, jeomorfolojik özellikler, ekonomik yapı, Suriye savaşı, nüfus değişimi.

\footnotetext{
${ }^{2}$ Arş.Gör. İskenderun Teknik Üniversitesi, E-mail: ztugba.guzel@iste.edu.tr

idealkent @ Kent Araştırmaları Dergisi (Journal of Urban Studies) 


\section{Introduction}

The settlement areas are defined as permanently or temporarily distributed build-up spaces that supply the humans' needs or requests. The formation, growth, and pattern distribution of the settlements are determined by natural geography on which the ecological boundaries have been located since ancient times (Hudson, 1969; Janečková Molnárová, Skřivanová, Kalivoda \& Sklenıčka, 2017; Long, Liu, Wu \& Dong, 2009; Sharma, 1969; Xi, Wang, Kong \& Zhang, 2015; Yang, Liu, Long, \& Qiao, 2015). The subject of the human settlement evolves with the ecological, locational, and landscape structures' links to roads, cultivation areas, buildings, and energy facilities in the whole city (Sharma, 1969; Stone, 1965). The city's accessibility and feasibility opportunities dramatically preoccupy how land characterizations are affected by population in terms of the settlement (Longley, Batty, Shepher \& Sadler, 1992). So, built settlements regarding geographic characters situate according to the man-land relationship that paralleled both the growth of economic and cultural dimensions (Hamerow, 2012; Stone, 1965; Yang et al., 2015). The city determines the developmental boundaries with its natural, economic, and political dependence on human factors.

When settlement geography expands according to the shaped natural boundary with regional economic, cultural, and aesthetical opportunities, grasping the landscape characteristics becomes crucial. Elevation and slope are two common and effective natural limitations that explain why settlement areas are distributed in their current locations. Several ancient civilizations such as Estonians, Egyptians, Mesopotamia, and Mesolictic Norway have preferred to live in the nearest location to any watercourse or yielding land where existing economic and foodstuff opportunities provided life assurance (Neogi, French, Durcan, Singh \& Petrie, 2020; Roalkvam, 2020; Sikk,Kriiska, Johanson, Sander \& Vindi, 2020; Yang, Xu, Xu \& Chen, 2019). Mediterranean cities are located also between mountains and coastal such as Italy, Norway, Spain, France (Mazzoleni, Di Martino, Strumia, Buonanno \& Bellelli, 2004; Olsson, Austrheim \& Grenne, 2000; Romero-Calcerrada \& Perry, 2004; Tatoni, Médail, Roche \& Barbero, 2004). Because these cities encourage society even today in terms of both the robust maritime economy, productivity, and social interactivity by the closeness of nature.

Besides agricultural (lowland) and coastal cities, mountain or hill cities shape and develop by their economic production potentials like timber and non-timber, or cultural habits of Australians, Europeans, and Asians despite 
of their problematic and remoteness locations (Chinea, 2002; Florentine \& Westbrooke, 2004; Kamada \& Nakagoshi, 1997; McDonald et al., 2000; Stzia, Sementazo \& Trentanovi, 2010). On the other hand, inhabitants of the ancient city of Inka, West Sierra Morena, and Lands of Antequera altered the landscape to exist the self-belonging residences in reason of their culture and religious ceremonies (Farrington, 1992; Moreno Escobar, Ojeda-Rivera \& García Sanjuán, 2020).

Modification of production systems are trigger points for the subdivision of settlements from town to metropolitan. Employee shortage of the established factories with industrialization and the destructive impacts of wars like World War II cause the ensemble global migration (Antrop, 1997; Ducruet, 2020; Godfrey \& Zhou, 1999). The population flow clarifies modification of settlement pattern, the size of why many immigrants settled in suburban, and the city distributes as an unpredictable form. So, demographic transition has advanced that the settlement size adjusted from farm-state to megalopolis and from monocentric to polycentric as a scatter pattern for urban areas (Table-1).

Table 1. Settlement diversity by housing density and population size (Carr, 1997, p. 127; The Geographer Online, 2021; Wood, 2017, p. 53).

\begin{tabular}{lll}
\hline Settlement Hierarcy & \multicolumn{2}{l}{ Size by population } \\
\hline Pattern by housing density & Isolated farm state & A few building \\
\cline { 2 - 3 } Isolated-Dispersed Settlement & Hamlet & $<100$ people \\
\cline { 2 - 3 } & Village & $100-1,000$ \\
\cline { 2 - 3 } & Small Town & $1,000-20,000$ \\
\hline \multirow{3}{*}{ Linear Settlement } & Large Town & $20,000-100,000$ \\
\cline { 2 - 3 } & City & $100,000-300,000$ \\
\cline { 2 - 3 } & Large city & $300,000-1$ million \\
\hline \multirow{3}{*}{ Agglomerated, Clustered, Compact, Nucleic } & Metropolis & $1-3$ million \\
\cline { 2 - 3 } & Conurbation & $3-10$ million \\
\cline { 2 - 3 } & Megalopolis & $10+$ million \\
\hline
\end{tabular}

Since industrialization, many industrial cities such as England, China, and the USA have swiftly transformed polycentric urban settlement structure into a megalopolis (Huang, Tan, Liu, Chu \& Kong, 2020; Kurnia devi, Mari Fitria, Roychansyah \& Herwangi 2020; Zheng \& Kahn, 2008). So, rural settlements have to reconstruct rural productions, lifestyles, natural systems, and sociocultural structures. In this alteration, the major reconstructed component is the economic structure that the urban-rural interaction dominates rather than the interplay of village-town systems. The rural settlement occurs in a closed 
system that attaches villages to the production areas while increasing urbanization causes the reshaping of these settlements from isolated, linear to agglomerated (Hudson, 1969; Peng, 2015; Zhou et.al., 2013).

Geomorphology is a critical component to predict the city's expansion and planning through physical dimensions with social amenities (Ozsahin \& Ozder, 2011; Poom, Ahas \& Orru, 2014). Considering the interplay between geomorphology and spatial distribution of settlements, these areas will construct and shape over nature to maintain a comfortable life. Turkey, which possesses several city formations due to geomorphology, shapes with different settlement typologies by its economic and social opportunities. Hatay is a significant city that benefits from Turkey's fertile lands, sea, and international connection with geologic characteristics. The existing socio-cultural and ecological capability of Hatay has enabled settlement diversity and density with the international economy.

The study aims to analyze the effect of different geomorphological characteristics in Hatay on the settlement size and form and to reveal the impact of social-economical and natural factors over the settlements typologies.

\section{Methodology}

In order to examine the interplay between the impact of geomorphology, climate, economy, political actions, and demographical flow on the settlement developments, the study aims to determine settlement size and pattern to interrogate economic, ecological structure within the land cover typologies of Hatay. The study that uses the explanatory research model focuses on the settlement size and form by the urban fabric, agricultural and natural types of Hatay's land cover. This research seeks answers to the following questions;

- What are the factors that affect the pattern of settlements together with the morphological structure in Hatay?

- Where is the economic structure located in urban settlement typologies?

- How does migration affect the pattern and size of settlements?

The study proceeded with literature review-situation analysis-result evaluation in three stages. The collected information in the literature review provides to determine how the settlement sizes and patterns of Hatay will analyze.

In the first stage of analysis, the size and pattern of the settlement areas are determined according to geomorphological data. In this scope, primary data of 
this research were obtained from GIS-based Corine Land Cover [CLC] maps developed by European Union in 2018 (European Environment Agency [EEA], 2021). This data is appropriate to investigate the relationship between settlement size and pattern with built-up (settlements, industrial and commercial units), natural structure (agriculture and watercourses) by benefiting from ArcGIS 10.5. Evaluation of Hatay's settlements patterns with obtained literature review from (Carr, 1997: 127; The Geographer Online, 2021; Wood, 2017: 53) actualized, while their location by CLC (2018), and their sizes by 2019 population data of Turkish Statistical Institute (TSI, 2019) analyzed. In the second stage of the study, the impact of natural and artificial economic structures on the determined settlement patterns was evaluated. While the economic structure of each city, agricultural lands, industry, commerce, and mining areas were examined in terms of size, the city's geomorphological structure and transportation facilities were included in the process. In addition, the effect of political relations of Hatay as a border city on transportation and economy was revealed. In the last stage, the interaction between population exchange and settlement patterns was analyzed considering the effects of the political actions of the city.

The evaluation phase revealed the relationship between the geomorphological character of each city, its prominent economic value, the opportunities provided by the transportation axes, and the shaping of settlement patterns with political intensity.

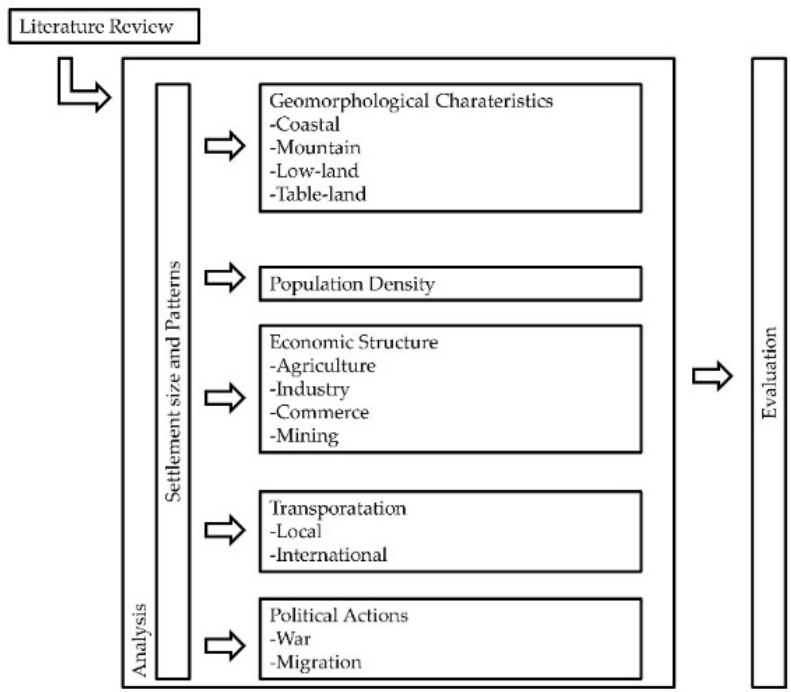

Figure 1. Methodologic flow (Guzel, 2021). 


\section{Study Area}

While the province of Hatay locates in the southernmost of Turkey to Figure $2 \mathrm{a}$, it forms with Syria borders of Turkey in the east and south, the provinces of Adana, Gaziantep, Osmaniye in the north. Also, it is limited by the Mediterranean in the West (Figure 2b). Besides the Mediterranean, the majority of Hatay's geomorphology shapes by the Amanos Mountains and river basins on its east and west sides, Amik low-land, Kuseyr tableland with developed green and blue structures. These existing natural formations providing economic and ecologic opportunities clarify why settlement areas occur, develop and expand in their locations. (Figure 2c).

Settlements patterns and sizes of Hatay diversified because of its location within the Asi River basin that enabled varied land morphologies. Amanos mountain is a unique ecological component that affects the distribution and formation of the city by restricting the transition between coastal and agricultural cities. The Mediterranean districts of Hatay are Arsuz, Iskenderun, Payas, Dortyol, and Erzin which are located throughout the coastal line and western side of Amanos. But Samandag, as a coastal district, is located on the Southern side of Amanos mountain. Iskenderun is one of the Mediterranean coastal district centers by which various products are exported or imported in the maritime transportation system (Doygun \& Alphan, 2006). Providing with the transportation axis despite the Amanos, Belen enables the flowing of products to national or international locations since the Ottoman period (Guzel \& Bozdogan Sert, 2020).

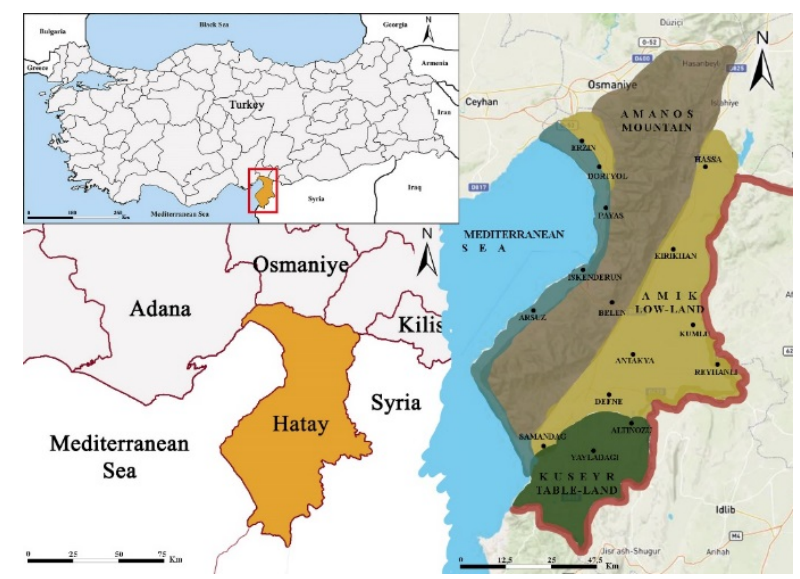

Figure 2. (a) The geographical location of the province in Turkey, (b) provincial boundaries of Hatay, (c) its settlement locations through natural dynamics (Guzel, 2021). 
The southern side of Amanos mountain is the popular settlement location because of the existing higher productivity areas of Amik lowland from the prehistoric period to the present. In this scope, multiple districts such as Antakya, Defne, Kirikhan, Reyhanli, Kumlu, Hassa locate into this lowland and its surrounding. Antakya is one of the central districts of Hatay, united through Defne district before the law amendment, distinguishes by its stratified city structure that developed with the marks of the Roman, Arabian, Byzantine, Seljuks, and Ottoman empires and the connection by Belen gate (Cetin, 2013; Ozsahin \& Ozder, 2011). Hatay was a township consisting of subdivisions and villages on Antakya before becoming a part of Turkey. The settlement region declared as a province by 9 its districts (Antakya, Iskenderun, Dortyol, Erzin, Yayladagi, Kirikhan, Reyhanli, Belen, Hassa) in 1939 (Adiguzel, 2014). After the inclusion to Turkey, the urban structure of Hatay consist and develop.

\section{Findings}

\section{Settlements of Hatay}

The settlement areas generally diversify according to geographical location, housing density, and population with natural and cultural structures. Geomorphological structure of Hatay primarily shapes its city formations as the coastal, lowland, tableland, and mountain. Coastal districts expand along the Mediterranean in terms of limited pertinent land, while the lowland and tableland districts are located over the most efficient lands between the hillside areas.

Coastal settlements generally occur as linear patterns due to watercourses, while the formation of mountain cities are as dispersed patterns between available land. But, Hatay's coastal districts are shaped by the clustered patterns except for Arsuz of which formation is linear pattern. The reason for the development of the reverse pattern relates to the unbalanced distribution of economic and social facilities in the coast. However, the climate characters of the city caused seasonal migration to the Belen and Arsuz as the most preferred locations for accommodation facilities and summer houses until now. In recent years, increasing climate change effects have triggered this demographic alteration (Cetin, 2013; Hatay Metropolitan Municipality, 2018; Kuscu \& Yigit, 2002). The mountain and tableland districts create dispersed patterns due to elevated topography like Belen, Altinozu, Yayladagi. 
The lowland districts like Antakya, Kirikhan, Reyhanli also form with clustered-dispersed patterns combination, while some of them such as Hassa, Kumlu, Defne, shape with large and small dispersed patterns related to production systems (Figure 3). The division of Antakya into two districts as Antakya and Defne at 2012 when Hatay's administration depended on the 6360 number Metropolitan Municipality Law, the settlement pattern of Antakya changed from clustered-linear form to clustered-dispersed form. Also, Iskenderun's clustered-linear-dispersed settlement pattern was altered by this administrative amendment that divided the district as Iskenderun, Payas, Arsuz.

Other geologic component like Habib-i Neccar Mountain (Hatay Province Yearbook, 1973: 139), affects the development of the urban patterns and sizes in the east and southeast directions. So, these diversities reveal that natural structure dramatically shapes the settlements, but it is not only one of the impacts.

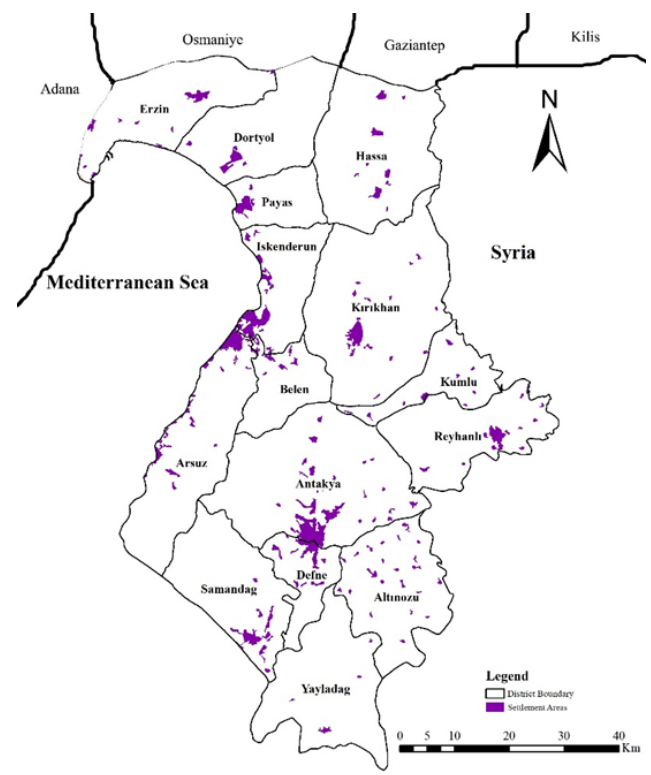

Figure 3. The distribution of settlement pattern by Corine 2018 (EEA, 2021).

Analyzing the physical dimension of the settlement according to the size revealed the following results: seven regions (Altinozu, Belen, Dortyol, Hassa, Payas, Kumlu, and Yayladagi) with a size under 1,000 hectares; five regions (Defne, Erzin, Kirikhan, Reyhanli, and Samandag) with a size between 1,000 
and 2,000 hectares; and three regions (Antakya, Arsuz, Iskenderun) with a size over 2,000 hectares (Table 2). Regarding the physical settlement area, Antakya has the highest residential area with 3,730.72 hectares. The highest proportion of residential areas to the surface areas was determined in Iskenderun and Defne by \%10. The settlement sizes of Iskenderun, Antakya, and Defne are compound and larger than others because of their service, production, education (university), transportation opportunities. Yayladagi $(227,05 \mathrm{ha})$ and Kumlu (464,77 ha) are smaller cities due to their restricted living resources as well as the location on the Syrian boundary.

The importance of population is the critical factor in the social aspect for the development of Hatay's settlement size and shape. When residential areas of Hatay determine by the settlements hierarchy literature regarding population, they consist of a small town (Kumlu), 7 large towns (Altinozu, Arsuz, Belen, Erzin, Hassa, Payas, Yayladagi), 6 cities (Defne, Dortyol, Iskenderun, Kirikhan, Reyhanli, Samandag), and 1 large city (Antakya). According to the social sizes results, Antakya and Kumlu are also distinctly separate from others in the settlement hierarchy. The management and political characteristics of Hatay with geography affect the size and patterns of the settlement. So the city services need to evaluate to figure out the settlement development.

Table 2. The location, pattern, and size of Hatay's settlements (Guzel, 2021).

\begin{tabular}{|c|c|c|c|c|c|c|c|c|c|c|c|c|c|c|}
\hline & \multicolumn{4}{|c|}{ Location } & \multicolumn{3}{|c|}{ Pattern } & \multicolumn{7}{|l|}{ Size } \\
\hline & \multirow[b]{2}{*}{ 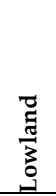 } & \multirow[b]{2}{*}{$\begin{array}{l}\text { 元 } \\
\text { 足 } \\
\tilde{u}\end{array}$} & \multirow[b]{2}{*}{ 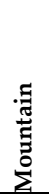 } & \multirow[b]{2}{*}{ 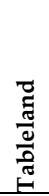 } & \multirow[b]{2}{*}{ 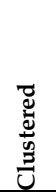 } & \multirow[b]{2}{*}{ 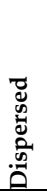 } & \multirow[b]{2}{*}{$\stackrel{\Xi}{\Xi}$} & \multicolumn{2}{|l|}{ Physical } & \multirow{2}{*}{ 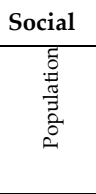 } & \multirow[b]{2}{*}{ 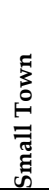 } & \multirow[b]{2}{*}{ 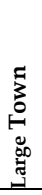 } & \multirow[b]{2}{*}{$\overrightarrow{0}$} & \multirow[b]{2}{*}{ 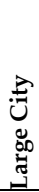 } \\
\hline & & & & & & & & 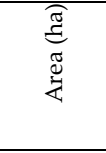 & $\begin{array}{l}\frac{\partial}{0} \\
\frac{\pi}{\pi} \\
\approx\end{array}$ & & & & & \\
\hline Antakya & $x$ & & $x$ & & $x$ & $x$ & & $3.730,72$ & 5 & 383.354 & & & & $x$ \\
\hline Altinozu & & & & $x$ & & $x$ & & 881,56 & 2 & 60.745 & & $\mathrm{x}$ & & \\
\hline Arsuz & $x$ & $\mathrm{x}$ & & & & & $\mathrm{x}$ & $2.384,75$ & 5 & 92.749 & & $\mathrm{x}$ & & \\
\hline Belen & & & $x$ & & & $x$ & & 559,02 & 3 & 33.313 & & $\mathrm{x}$ & & \\
\hline Defne & $x$ & & & $x$ & $x$ & & & $1.555,31$ & 10 & 154.820 & & & $\mathrm{x}$ & \\
\hline Dortyol & $\mathrm{x}$ & & $x$ & & $x$ & & & 754,21 & 2,2 & 125.138 & & & $\mathrm{x}$ & \\
\hline Erzin & $x$ & & $x$ & & & $x$ & & $1.100,07$ & 4,2 & 41.463 & & $x$ & & \\
\hline Hassa & $\mathrm{x}$ & & $x$ & $x$ & & $x$ & & 924,65 & 1,7 & 56.519 & & $x$ & & \\
\hline Iskenderun & & $x$ & & & $x$ & $x$ & & $2.605,97$ & 10,5 & 248.380 & & & $x$ & \\
\hline Kirikhan & $\mathrm{x}$ & & & & & $x$ & & $1.455,23$ & 2 & 116,876 & & & $\mathrm{x}$ & \\
\hline Kumlu & $x$ & & & & & $x$ & & 464,77 & 2,4 & 13.686 & $x$ & & & \\
\hline Payas & & $\mathrm{x}$ & $x$ & & $x$ & & & 758,89 & 4,8 & 42.477 & & $x$ & & \\
\hline Reyhanli & $\mathrm{x}$ & & & & & $x$ & & $1.178,70$ & 3,2 & 100.151 & & & $x$ & \\
\hline Samandag & $x$ & $x$ & & $\mathrm{x}$ & $\mathrm{x}$ & & & $1.420,67$ & 3,7 & 122.223 & & & $x$ & \\
\hline Yayladagi & & & & $\mathrm{x}$ & & $x$ & & 227,05 & 0,05 & 37.000 & & $x$ & & \\
\hline
\end{tabular}




\section{Impact of economic structure on settlements}

The economic structure of Hatay consists of developing production systems with mining fields, natural agricultural lands, industrial areas. The existing higher production level of Hatay shows the consistent economic status with export and import axes functionalized from past to present. Therefore, settled districts of Hatay via geographical structure are developed within existing production potential and international transportation systems. Actual various fertilizer deltas have generated the majority of the economy for Hatay and its environment (Figure 4). The government generally supported the natural production system. The agricultural production of the city diversifies since products are grown on trees or arable fields as grove and field farming (Hatay Governorship, 2019).

In Amik, Arsuz, and a small part of Erzin lowlands as the major arable areas, cereals, legumes, vegetables, etc. are cultivated. Almost all of the surface areas of Kumlu (91\%) and Reyhanli (83\%) are covered by arable areas. However, Kirikhan (72.5\%), Defne (57\%), and Antakya (49\%) in the Amik lowland have operated a significant part of annual farming. The agriculture production on the coastal side reinforces by the biggest arable areas of Erzin (37\%), and Arsuz (35\%). Grove areas and productions are more limited than arable areas. The most grove areas are in Altinozu (52\%) and Erzin (43\%) (Table 3). Grove products such as olive, citrus, nuts, and fruits mainly grow in residential gardens but supporting the economy through personal sale and factory production. Based on the observed results, Kumlu, Altinozu, Yayladagi, and Reyhanli which have a density of agricultural lands are shaped by small dispersed residential areas. Certain parts of Kirikhan and Antakya are also in this group.

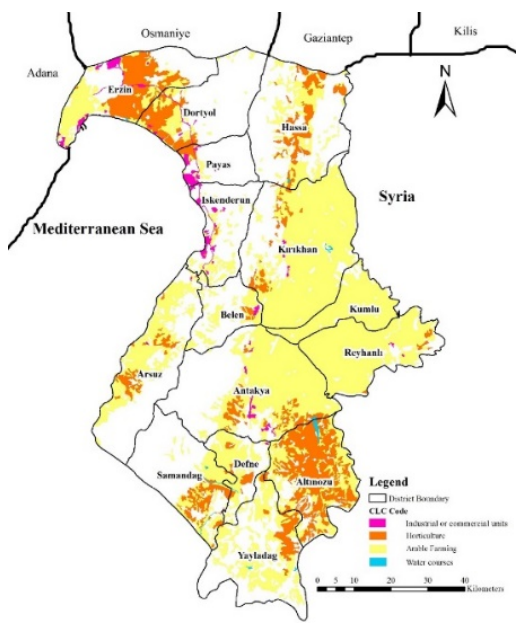

Figure 4. Arable farming, grove, and industrial areas of Hatay (produced from Corine 2018). 
Table 3. The distribution of natural and artificial economic structure over the cities with CLC report, and 2019 Activity Report (EEA, 2021; Hatay Provincial Directorate of Industry and Technology, 2018).

\begin{tabular}{lcccccc}
\hline & \multicolumn{2}{c}{ Arable Farming } & $\begin{array}{l}\text { Grove (Special } \\
\text { Garden) }\end{array}$ & \multicolumn{2}{l}{$\begin{array}{l}\text { Industrial, commercial, } \\
\text { transportation and mining } \\
\text { areas }\end{array}$} \\
\hline Antakya & $\begin{array}{c}\text { Area } \\
\text { (ha) }\end{array}$ & $\begin{array}{c}\text { Rate } \\
\text { (\%) }\end{array}$ & $\begin{array}{c}\text { Area } \\
\text { (ha) }\end{array}$ & $\begin{array}{c}\text { Rate } \\
\text { (\%) }\end{array}$ & Area (ha) & Rate (\%) \\
\hline Altinozu & $9,809.88$ & 50 & $3,870.87$ & 5 & $\mathbf{1 , 0 2 6 . 8 3}$ & 1 \\
\hline Arsuz & $16,152.16$ & 35 & $2,708.21$ & 6 & 48.37 & - \\
\hline Belen & $4,891.86$ & 26.75 & 595.74 & 3,25 & 218.39 & 1 \\
\hline Defne & $8,832.37$ & 57 & $1,119.89$ & 7 & 35.57 & 0.2 \\
\hline Dortyol & $4,122.04$ & 13 & $5,389.23$ & 15 & 155.0 & 0.4 \\
\hline Erzin & $9,511.97$ & 37 & $\mathbf{1 1 , 0 8 2 . 8 3}$ & 43 & $\mathbf{1 , 4 4 1 . 9 3}$ & 5.6 \\
\hline Hassa & $10,529.4$ & 20 & $6,677.6$ & 13 & - & - \\
\hline Iskenderun & $4,275.82$ & 16.5 & 122.01 & 0,5 & $\mathbf{1 , 3 9 4 . 4 9}$ & 5.6 \\
\hline Kirikhan & $\mathbf{5 2 , 1 3 0 . 4 1}$ & 72.5 & $1,911.27$ & 2,5 & 218.50 & 0.3 \\
\hline Kumlu & $17,556.28$ & 91 & - & - & - & - \\
\hline Payas & 936.8 & 6 & 748.72 & 5 & $\mathbf{1 , 1 6 5 . 1 2}$ & 7.4 \\
\hline Reyhanli & $\mathbf{3 0 , 9 0 7 . 1 5}$ & 83.8 & 439.06 & 1,2 & 84.07 & 0.2 \\
\hline Samandag & $6,839.64$ & 18 & $3,905.63$ & 10 & - & - \\
\hline Yayladagi & $16,388.98$ & 37 & $3,526.18$ & 8 & - & - \\
\hline
\end{tabular}

Available production potencials provide the building of industrial facilities in the northern coastal and lowland sides for the processing of food products, heavy materials and minerals. The industrial production zones of Hatay, which occur from heavy industry factories and mines, develop and distribute by the impact of the Adana-Iskenderun railway, Belen gate, and the Mediterranean. For coastal districts, the development of settlement patterns is associated with the industry, even if the beginning of the settlements occurred by agricultural productions.

The district structure of Payas by $7.4 \%$, Iskenderun by $5.6 \%$, and Erzin by $5.6 \%$ have mostly been affected by the railway. These districts located along the existing transportation axis route enable the development of settlement patterns with clustered residential areas. Antakya has just triggered how the settlement pattern modify with the sprawl of mines and organized industrial areas by Iskenderun-Belen-Antakya axis. This axis associated with other routes has also enabled the development of industrial facilities in Belen, Kirikhan, and Reyhanli. In this scope, Kirikhan and Reyhanli, which were shaped with 
rural isolated settlements, have evolved into a large clustered urban pattern nearby the industrial zones.

Business opportunities that occur in the intensive settlement areas cause a higher population in the industrial zones than in agricultural cities. Increased industrial areas of Iskenderun, Payas, Antakya et., located far from the city, cause the development of small-large settlements to satisfy the needs of their inhabitants. Nonetheless, the general economic approach of Hatay progresses by the connection between industry and agricultural production in Antakya, Kirikhan, Defne, Reyhanli. According to the 2018 production report, agricultural products (\%26.33) were the first resource in the sectoral distribution of industry, while the main material $(\% 34,37)$ facilities were the largest employment opportunity of society (Table 4).

Table 4. The integration between sectoral distributions and employment in Hatay's industry according to the 2018 Industrial status report (Turkey Ministry Industry and Technology, 2018).

\begin{tabular}{lllll}
\hline & Sectoral Distribution & Rate & Employment Distribution & Rate \\
\hline $\mathbf{1}$ & Agricultural products & $26.22 \%$ & Main material & $34.37 \%$ \\
\hline $\mathbf{2}$ & Furniture & $15.94 \%$ & Agricultural products & $12.89 \%$ \\
\hline $\mathbf{3}$ & Wood and cork products & $10.77 \%$ & Machinery and equipment & $11.43 \%$ \\
\hline $\mathbf{4}$ & Rubber and Plastic & $8.71 \%$ & Metal products & $6.14 \%$ \\
\hline $\mathbf{5}$ & Metal products & $5.88 \%$ & Rubber and Plastic & $4.97 \%$ \\
\hline $\mathbf{6}$ & Machinery and equipment & $5.11 \%$ & Chemical products & $4.93 \%$ \\
\hline $\mathbf{7}$ & Non-metallic mineral products & $4.95 \%$ & Textile & $4.28 \%$ \\
\hline $\mathbf{8}$ & Leather products & $4.57 \%$ & Furniture & $6.69 \%$ \\
\hline $\mathbf{9}$ & Main material & $3.21 \%$ & Non-metallic mineral products & $3.5 \%$ \\
\hline $\mathbf{1 0}$ & Chemical products & $2.72 \%$ & Wood and cork products & $2.83 \%$ \\
\hline
\end{tabular}

Being a part of the three ancient unique metropolises of the World, Hatay has been a dominant trade and industrial city as a landmark of the EuropeanAsian trade axis since the Roman-Byzantian period with eight thousand years of history (Candeger, 2019; Kaypak, 2016). With its natural production potential and advanced economic opportunities, Hatay has enabled the development of Turkey's oldest residential areas. The development of the historical trade axis, the spread of industrial sites, and organized industrial areas throughout the city caused unplanned urbanization on settlement patterns that started in Antakya. Urban sprawl has developed complex settlement patterns throughout the city (Adiguzel, 2014; Adiguzel \& Tek, 2011). Thus, scattered settlement patterns developed due to agriculture in many districts such 
as Reyhanli, Defne, Kirikhan, Hassa, Belen, Iskenderun, Payas, Erzin transshaped into dispersed-clustered settlement patterns.

This commercial movement axis, which initiates from the Reyhanli and Yayladagi border gates, has added international value to Hatay with the connection by Syria. As the axis maintained export and import of local outputs with the connection between sea and land until now, the Syrian war negatively affected this international economic flow (Figure 5).

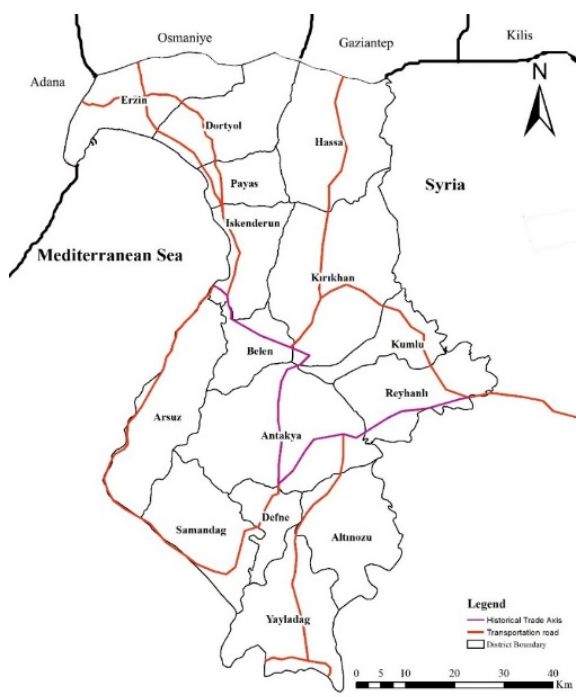

Figure 5. Current transportation system integration between cities that shape with different geomorphological structures, and representation of Turkish-Syrian trade axis (Guzel, 2021).

Political borders are the factors that both separate and unite the states like the Turkey-Syria connection. Since Hatay constantly interacts with Syria in terms of economic, social, and cultural structure because it was a district connected to Aleppo until the 20th century. After the inclusion of Hatay in Turkey, the kinship relations, and commercial interaction have provided the countinuum of public holistic structure. So, residential areas on the border (mainly Reyhanli) developed by the protection of cultural loyalty, and ensured the positive impact of political interplay between Turkey and Syria. In addition, several people migrated for business opportunities to the Middle East and Asian countries through the border gates until the 2000s. However, many of the immigrants repatriate to their country after saving money (Cetin, 2010). The city's social and economic disruption began with the development of physical and administrative limiters to protect the city from terrorism after 
1960, while these limiters also triggered the reciprocal ensemble migrations (Atasoy, Gecen \& Korkmaz, 2012).

The Syrian civil war has transformed the socio-economic structure of Turkey by reason of mass migration since 2011. Hatay, like several cities, has offered comfortable living arrangements for 439,450 from approximately 4 million refugees that constitute $27 \%$ of the whole population. These refugees live either camp areas (16,683 people) in Altinozu, Yayladagi, and Antakya or in cities like Reyhanli, Antakya that have business opportunities in various sectors with lower prices (Hatay Governorship, 2020; Onder, 2019). While the mass migration wave caused unplanned urbanization by exceeding the bearing capacity of the cities, it disrupted the social and cultural relations of Turks and Syrians.

\section{Results and Discussion}

While the formation of settlements shape according to geomorphology, their patterns and sizes shift depending on the usage of the natural potentials. According to the literature, Gundogan (2020) determined that the settlement patterns of Anatolian cities in different geographical locations varied according to their cultural and social structures in the third century BC, while Danso Wiredu et.al., (2020) also mentioned that social, economic, and political resources affected the development of modern Ghana cities in different locations. Settlement areas of Hatay that are located in four different urban morphologies produce four different urban patterns: dispersed, clustered, linear, and clustered-dispersed. The relationship between the natural structure and the city, which adjusts depending on morphology in the region, causes the distinction of settlement patterns that receive economic, transportation, political targets for increasing development level. If the main focus sustains as the economy, the disengagement of the nature-city relationship, land degradation, unpredictable land sprawl can actualize.

Plain, tableland, and mountainous settlements of Hatay are generally associated with the natural structure for agriculture and accessibility purposes. While hillside and lowland districts mainly shape with diverse size dispersed urban patterns, mixed settlement patterns (dispersed-clustered) observe in some parts with the impact of industrial and commercial axes. However, the impact of seasonal migration due to climate is effective in the settlement patterns growth by advancing transportation and commercial activities throughout the city, especially in Belen and Arsuz. According to Poom et al. (2014), 
if transportation opportunities of cities increase, settlement patterns and sizes also vary. Ewing, and Cervero (2010) state that different-purpose roads are diversification factors for the settlement patterns. Economic opportunities provided by the international trade line of Syria-Turkey have led to the beginning of the present Antioch settlement formation. The existing axes of the city for industrial, commercial, and social purposes, developed within the socio-economic possibilities, enable the settlement patterns to create both linear forms at the roadside and clustered patterns at the central points (Figure 6).

The economic structure of Hatay has two centers (Antakya, Iskenderun) that create production and distribution opportunities and are framed with a complex pattern. In this context, developed industrial roads in coastal settlements have caused divergent expansion in the settlement pattern of Iskenderun and its vicinities from linear to clustered settlement patterns. This is because industrial facilities and transportation routes in this region interrupt the public's communication with the sea. Antakya as an international trade center and a city center has a clustered settlement pattern. Although the city center is not a metropolis like Athen, Rome (Zambon, Serra, Sauri, Carlucci \& Salvati, 2017), London, or Berlin (Arapoglou, 2012), Antakya has the highest size and the deepest historic settlement in the region.

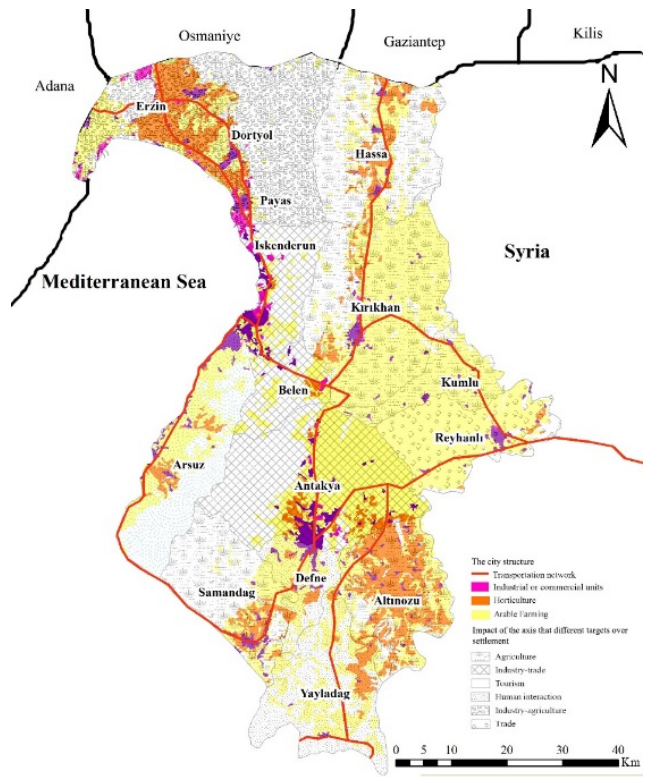

Figure 6. Evaluation of the relationship between settlement patterns and the transportation axes that develop accord to the city's economic structure (Guzel, 2021). 
The increasing concentration of residential area by bussiness oppurtunities in service sector of Antakya (tourism, food-beverage, administrative) evolves the settlement pattern and size. According to Capello, and Camangi, (2000), occured comfortable living conditions through clustered urban patterns annihilate because of degraded and decreased production areas. The organized industrial areas in the transportation axis and the small industrial sites located on the agricultural districts were efficient in the occupation of the fertile lands. However, The urban pattern of Arsuz evolves in a linear form because of local and national tourist facilities and socially accessible roads. Therefore, land-use decisions of cities expect for their natural potentials are effective in the diversification of settlement patterns. While the actualized economic corridor in China-Mongolia-Russia similarly improved the economy, tourism activities, and infrastructure, the population density increased in the surrounding of the transition development zone in Mongolia. (Osodoev \& Zhamyanova, 2021). As generated trade axis triggered the population density, the settlement size and shape affect from it. So, existing conditions in public areas should strictly review, appropriate urban-rural zonning plan should create for social satisfaction.

While economic relations with Syria are the cause of cultural and social interaction, they have also led to the development of the settlement area dominated by Syrians in the Reyhanl region. Ethnic status wasn't a problem in this region before the refugees came in 2012. But existing more advantages rather the local inhabitants, and swiftly increased their population, caused the inconveniences accord to ethics. So, they must reside in the suburbs as occurred a similar situation in Europe (Benassi, Iglesias-Pascual \& Salvati, 2020). Ethnic diversity is also determinant in the transformation of the clustering urban pattern. New settlements were generated by German refugees on the German-Polish border due to the 1919-1939 German civil war (Eawniczak \& Kubiak, 2021). Therefore, political relations of cities can lead to sudden changes in the settlement pattern and size.

Settlement areas of Hatay were classified into four groups with four patterns, while the patterns were altered by the existence of economic structure. In this scope, the settlement pattern was determined as dispersed-clustered in the industrial region, linear in the tourism zone, and dispersed in the agricultural production zone. As the land-use and political relations of cities are also a part of the settlement process, the administration should be balance the local investments, the localization facilities for planning decisions. 
As a result, while geomorphological structures of Hatay provide the formation of settlement patterns, the presence of inner dynamics (economic developments, transportation, climate) and exterior dynamics (political relations) are effective in structureless pattern development. The urban development program should create according to the local and international history of the city, with the natural-cultural environment analysis and the employed sectors and impact areas.

\section{Acknowledgment}

The author acknowledges the support of Prof. Dr.Tuzin Baycan pioneered the development of this study in the Urban System course.

\section{Kaynakça/References}

Adiguzel, S. (2014). Hatay büyükşehir belediyesi. [Hatay metropolitan municipality]. Adnan Menderes Üniversitesi Sosyal Bilimler Enstitüsü Dergisi, 1(5), 54-76. 10.30803/adusobed.188829.

Adiguzel, S. \& Tek, M. (2011). Büyükşehir belediyesi olma sürecinde Antakya metropoliten alaninda yerel siyaset. [Local politics in the metropolitan area of Antakya in the process of becoming metropolitan municipality]. Çă̆daş Yerel Yönetimler Dergisi, 20(4), 73-95.

Alp, H., Albora, A. M. \& Tur, H. (2011). A view of tectonic structure and gravity anomalies of Hatay Region Southern Turkey using wavelet analysis. Journal of Applied Geophysics, 75(3), 498-505. 10.1016/j.jappgeo.2011.07.004.

Antrop, M. (1997). The concept of traditional landscapes as a base for landscape evaluation and planning. The example of Flanders Region. Landscape and Urban Planning, 38(1-2), 105-117. https://doi.org/10.1016/S0169-2046(97)00027-3.

Arapoglou, V. P. (2012). Diversity, inequality and urban change. European Urban and Regional Studies, 19(3), 223-237. https://doi.org/10.1177\%2F0969776412451800.

Atasoy. A., Gecen. R. \& Korkmaz. H. (2012). Siyasi coğrafya açısından Türkiye(Hatay)-Suriye sinırı [Turkey (Hatay)-Syrian border in terms of political geograhy]. TUCAUM VII. Coğrafya Sempozyumu Bildiriler Kitabı, Cilt 1 (s. 107-119), Ankara. Türkiye. http:/tucaum.ankara.edu.tr/tucaum-viiicografya-sempozyumu/

Benassi, F., Iglesias-Pascual, R. \& Salvati, L. (2020). Residential segregation and social diversification: Exploring spatial settlement patterns of foreign population in Southern European cities. Habitat International, 101, 102200. https://doi.org/10.1016/j.habitatint.2020.102200.

Candeger. U. (2019). Hatay'ın anavatana katılma sürecinde Reyhanlı kazası'nın sosyo-ekonomik yapisı (1939-1940). [The socio-economic structure of the 
Reyhanl district in Hatay's joining process to the homeland (1939-1940)]. S. Cereci ve N. Akhmetov (Eds.) 5. Uluslararası Kültür ve Medeniyet Kongresi Bildiriler Kitabı Cilt 1, s.145-157, IKSAD Yayınları. https://www.academia.edu/40783193

Canpolat, E., Dinc. Y., Usun, C. F. \& Gecen, R. (2020). 25.09.2014 tarihinde Erzin Ilıcalarda (Hatay) meydana gelen sel ve taşkının oluşumunda coğrafi faktörlerin değerlendirilmesi. [Evaluation of the geographical factors in the formation of flashflood and flood in Erzin-Ilicalar (Hatay) on September 25, 2014]. Coğrafya Dergisi, (41), http://dx.doi.org/10.26650/JGEOG2020-0048.

Capello, R. \& Camagni, R. (2000). Beyond optimal city size: an evaluation of alternative urban growth patterns. Urban Studies, 37, 1479-1496 https://doi.org/10.1080\%2F00420980020080221.

Carr, M. (1997). New patterns: Process and change in human geography. Chapter 12, (s. 120-137). UN. Thomas Nelson and Sons Publishing. https://books.google.com.tr/books?id=71KIMAS_7hoC

Cetin, B. (2010). Antakya (Hatay) nüfusunun 1940-2008 yılları arasındaki gelişimi ve temel özellikleri. [The development and basic characteristics of the population of Antakya (Hatay) between 1940-2008]. A. Gunduz \& S. Kaya (Eds), Hatay Araştırmaları I, Cilt 1 (s. 179-225), Pegem Yayınları. https://www.researchgate.net/publication/335754062

Cetin, B. (2013). Hatay'da kentleşmenin seyri (1940-2009) ve mekânsal dağılışı. [The course of urbanization (1940-2009) and its spatial dispersion in Hatay]. Doğu Coğrafya Dergisi, 17(28), 231-258. https://dergipark.org.tr/en/pub/ataunidcd/issue/2456/31293.

Chinea, J. D. (2002). Tropical forest succession on abandoned farms in the Humacao municipality of eastern Puerto Rico. Forest Ecology and Management, 167(1-3), 195-207, https://doi.org/10.1016/S0378-1127(01)00693-4.

Danso Wiredu, E.Y., Mensah, B., Darkwa, I. O., Bonful., E. Tuu., M.B. \& Mohammed, S. (2020). Patterns of land use activities in Ghana's secondary cities, Ghana Journal of Geography, 12(2), 84-107. https://doi.org/10.4314/gjg.v12i2.4.

Ducruet, C. (2020). Revisiting urban hierarchy and specialization from a maritime perspective. Maritime Policy $\mathcal{E}$ Management, 47(3), 371-387. https://doi.org/10.1080/03088839.2019.1693065.

Doygun, H. \& Alphan, H. (2006). Monitoring urbanization of Iskenderun, Turkey, and its negative implications. Environmental Monitoring and Assessment, 114(1), 145155. https://doi.org/10.1007/s10661-006-2524-0.

European Environment Agency. (2021, 11 January). CORINE 2018 Metadata, https://land.copernicus.eu/pan-european/corine-land-cover/clc2018

Ewing, R. \& Cervero, R. (2010), Travel and the built environment. Journal of the American Planning Association. 76 , 265-294. https://doi.org/10.1080/01944361003766766. 
Farrington, I. S. (1992). Ritual geography, settlement patterns and the characterization of the provinces of the Inka heartland. World Archaeology-Archaeology of Empires, 23(3), 368-385. https://doi.org/10.1080/00438243.1992.9980186.

Florentine, S. K. \& Westbrooke, M. E. (2004). Evaluation of alternative approaches to rainforest restoration on abandoned pasturelands in tropical north Queensland, Australia. Land Degradation \& Development, 15(1), 1-13. https://doi.org/10.1002/ldr.586.

Godfrey, B. J. \& Zhou, Y. (1999). Ranking world cities: multinational corporations and the global urban hierarchy. Urban geography, 20(3), 268-281. https://doi.org/10.2747/0272-3638.20.3.268.

Gundogan, U. (2020). The "Aegean settlement pattern" in coastal Western Anatolia from the Neolithic age to the end of the 3rd Millennium BC. TÜBA-AR-Turkish Academy of Sciences Journal of Archaeology, (27), 29-43. https://doi.org/10.22520/tubaar2020.27.002.

Guzel, Z. T. \& Bozdogan Sert, E. (2020). Analysing the land use alteration's impact in the district of Belen (Hatay) on the natural and built environment by using Corine data. Kastamonu University Journal of Engineering and Sciences, 6(2), 73-83 https://dergipark.org.tr/en/pub/kastamonujes/issue/58573/822727.

Hamerow, H. (2012). Rural settlements and society in Anglo-Saxon, London. Oxford University Press. 10.1093/acprof:oso/9780199203253.001.0001

Hatay Governorship (2019). Activity report of Province Directorate of Agriculture and Forestry. https://hatay.tarimorman.gov.tr/Menu/55/Tarimsal-Veriler

Hatay Governorship. (2020, 21 September). Population and its distribution, http://www.hatay.gov.tr/nufus-ve-dagilimi

Hatay Metropolitan Municipality. (2018). Suriye'deki iklim değişikliğinin ve susuzluğun Türkiye'ye olan Suriyeli göçüne etkisinin Hatay özelinde araştırılması. [Investigation of climate change and thirst effects in Syria on Syrian immigrants in the case of Hatay]. AB Proje Raporu. https://www.iklimin.org/tr/

Hatay Provincial Directorate of Industry and Technology. (2018). Hatay Provincial Industry Status Report, https://www.sanayi.gov.tr/

Hatay Province Yearbook. (1973). Cumhuriyetin 50.yılında Hatay. [Hatay on the 50th anniversary of the Republic]. Milli Eğitim Basımevi.

Huang, D., Tan, X., Liu, T., Chu, E. \& Kong, F. (2020). Effects of hierarchical city centers on the intensity and direction of urban land expansion: A case study of Beijing. Land, 9(9), 312. https://doi.org/10.3390/land9090312.

Hudson, J. C. (1969). A location theory for rural settlement. Annals of The Association of American Geographers, 59(2), 365-381. https://doi.org/10.1111/j.14678306.1969.tb00676.x.

Janečková Molnárová, K., Skřivanová, Z., Kalivoda, O. and Sklenička, P. (2017). Rural identity and landscape aesthetics in exurbia: Some issues to resolve from a 
Central European perspective. Moravian Geographical Reports, 25(1): 2-12. https://doi.org/10.1515/mgr-2017-0001.

Kamada, M. \& Nakagoshi, N. (1997). Influence of cultural factors on landscapes of mountainous farm villages in Western Japan. Landscape and Urban Planning, 37(1-2), 85-90. https://doi.org/10.1016/S0169-2046(96)00372-6.

Kaypak, S. (2016), Demokrasi kültürü ve hoşgörü: Hatay örneğinde. [Culture of democracy and tolerance; in Hatay example]. R. Pehlivanlı \& S. Demirkılınç (Eds). 2. Uluslararası Çin'den Adriyatik'e Sosyal Bilimler Kongresi Kongre Kitabı, Uluslararası İlişkiler- Kamu Yönetimi-Hukuk Özel Sayısı, (s. 147-160), IKSAD Yayınları. https://www.academia.edu/32188150

Kurnia devi, M., Mari Fitria, L., Roychansyah, M. S. \& Herwangi, Y. (2020). Measuring urban form units: Alternative for characterizing urban growth pattern in Yogyakarta urbanized areas, Indonesian Journal of Geography, 52(2), 219-226. https://doi.org/10.22146/ijg.40599.

Kuscu, V. \& Yigit, A. (2002). İskenderun Körfezi ve Şanlıurfa Platosu arasında iklimde görülen değişmeler. [The climatic changes between Iskenderun Gulf and Sanlıurfa Plateu]. S. Onder (Ed). Su Havzalarında Toprak ve Su Kaynaklarının Korunması, Geliştirilmesi ve Yönetimi Sempozyumu Bildiri Kitabı. Cilt 1 (s. 302309). https://www.academia.edu/22473229

Ławniczak, R. \& Kubiak, J. (2021). Changes in the settlement network in the Noteć Forest (Poland) in a historical perspective. Journal of Maps, 1-9. https://doi.org/10.1080/17445647.2020.1866701.

Long, H., Liu, Y., Wu, X. \& Dong, G. (2009). Spatio-temporal dynamic patterns of farmland and rural settlements in Su-Xi-Chang region: Implications for building a new countryside in coastal China. Land Use Policy, 26(2), 322-333. https://doi.org/10.1016/j.landusepol.2008.04.001.

Longley, P., Batty, M., Shepherd, J. \& Sadler, G. (1992). Do green belts change the shape of urban areas? A preliminary analysis of the settlement geography of South East England. Regional Studies, 26(5), 437-452. https://doi.org/10.1080/00343409212331347101.

McDonald, D., Crabtree, J. R., Wiesinger, G., Dax, T., Stamou, N., Fleury, P., ... \& Gibon, A. (2000). Agricultural abandonment in mountain areas of Europe: Environmental consequences and policy response. Journal of Environmental Management, 59(1), 47-69. https://doi.org/10.1006/jema.1999.0335.

Mazzoleni, S., Di Martino, P., Strumia, S., Buonanno, M. \& Bellelli, M. (2004). Recent changes of coastal and submountain vegetation landscape in Campania and Molise Regions in Southern Italy. In: S. Mazzolen, G. D1 Pasquale, P. D1 Martıno, F. Rego, M. Mulligan (Eds). Recent dynamics of Mediterranean Vegetation Landscape. 143-155, John Wiley \& Sons. https://books.google.com.tr/books?id=s88vzd9PwkkC\&pg

Moreno Escobar, M. D. C., Ojeda-Rivera, J. F. \& García Sanjuán, L. (2020). Effects of Roman rule on the settlement geography of South Iberia: a GIS-based 
approach. Oxford Journal of Archaeology, 39(2), 189-212. https://doi.org/10.1111/ojoa.12187.

Neogi, S., French, C. A., Durcan, J. A., Singh, R. N. \& Petrie, C. A. (2020). Geoarchaeological insights into the location of Indus settlements on the plains of Northwest India. Quaternary Research, 94, 137-155. https://doi.org/10.1017/qua.2019.70.

Olsson, E. G. A., Austrheim, G. \& Grenne, S. N. (2000). Landscape change patterns in mountains, land use and environmental diversity, Mid-Norway 1960-1993. Landscape Ecology, 15(2), 155-170. https://doi.org/10.1023/A:1008173628016.

Onder, N. (2019). Türkiye'de geçici koruma altındaki Suriyelilere yönelik sağlık politikalarının analizi. [The analysis of health policies to temporarily protected Syrians in Turkey]. Göç Araştırmaları Dergisi, 5(1), 110-165. https://dergipark.org.tr/en/pub/gad/issue/48924/624009

Osodoev, P. V. \& Zhamyanova, Y. B. (2021). Features of the population settlement system in the regions of the China-Mongolia-Russia economic corridor. In IOP Conference Series: Earth and Environmental Science, 629(1). 012021. IOP Publishing. doi:10.1088/1755-1315/629/1/012021.

Ozsahin, E. \& Ozder, A. (2011). Antakya şehri ve jeomorfolojik birimler arasındaki ilişkinin zamansal değişimi (Hatay). [The temporal alteration of the interrelation between morphological units and Antakya district (Hatay)]. Fiziki Coğrafya Araştırmaları, 657-680. https://www.academia.edu/3073829

Peng, Y. (2015). A comparison of two approaches to develop concentrated rural settlements after the 5.12 Sichuan Earthquake in China. Habitat International, 49, 230-242. https://doi.org/10.1016/j.habitatint.2015.05.027.

Poom, A., Ahas, R. \& Orru, K. (2014). The impact of residential location and settlement hierarchy on ecological footprint. Environment and Planning A, 46(10), 23692384. https://doi.org/10.1068\%2Fa140059p.

Roalkvam, I. (2020). Algorithmic classification and statistical modeling of coastal settlement patterns in mesolithic south-eastern Norway. Journal of Computer Applications in Archaeology, 3(1). http://doi.org/10.5334/jcaa.60.

Romero-Calcerrada, R. \& Perry, G. L. (2004). The role of land abandonment in landscape dynamics in the SPA 'Encinares del río Alberche y Cofio, Central Spain, 1984-1999. Landscape and Urban Planning, 66(4), 217-232. https://doi.org/10.1016/S0169-2046(03)00112-9.

Sharma, R. C. (1969). An appraisal of settlement geography with reference to India, The Professional Geographer, 21(3): 158-162, https://doi.org/10.1111/j.00330124.1969.00158.x.

Sikk, K., Kriiska, A., Johanson, K., Sander, K. \& Vindi, A. (2020). Environment and settlement location choice in stone age estonia. Estonian Journal of Archaeology, 2, 89-140. http://dx.doi.org/10.3176/arch.2020.2.01.

Stzia, T., Semenzato, P. \& Trentanovi, G. (2010). Natural reforestation is changing spatial patterns of rural mountain and hill landscapes: A global overview. 
Forest Ecology and Management, 259(8), 1354-1362. https://doi.org/10.1016/j.foreco.2010.01.048.

Stone, K. H. (1965). The development of a focus for the geography of settlement. Economic Geography, 41(4), 346-355. https://doi.org/10.2307/141945.

Tatoni, T., Médail, F., Roche, P. \& Barbero, M. (2004). The impact of changes in land use on ecological patterns in Provence (Mediterranean France). S. Mazzoleni, G. D. Pasquale, M. Mulligan, P. D. Martino, F. Regp (Eds), Recent dynamics of the Mediterranean vegetation and landscape, Chapter 10. (s. 105-120). Wiley. https://doi.org/10.1002/0470093714.ch10.

The Geographer Online. (2021, 20 January). Settlement patterns and settlement hierarchy, https://www.thegeographeronline.net/settlements.html.

Turkish Statistical Institute. (2019). Migration by provinces, net migration and net migration rate, general population censuses, https://data.tuik.gov.tr/Kategori/GetKategori?p=nufus-ve-demografi109\&dil=1

Wood, D. (2017). The new wider world coursemate for standard grade geography. Second Edition. Thomas Nelson and Sons Publishing, UN. https://books.google.com.tr/books?id=vnZNZUb_5e0C

Xi, J., Wang, X., Kong, Q. \& Zhang, N. (2015). Spatial morphology evolution of rural settlements induced by tourism. Journal of Geographical Sciences, 25(4), 497-511. https://doi.org/10.1007/s11442-015-1182-y.

Yang, R., Liu, Y., Long, H. \& Qiao, L. (2015). Spatio-temporal characteristics of rural settlements and land use in the Bohai Rim of China. Journal of Geographical Sciences, 25(5), 559-572. https://doi.org/10.1007/s11442-015-1187-6.

Yang, R., Xu, Q., Xu, X., \& Chen, Y. (2019). Rural settlement spatial patterns and effects: Road traffic accessibility and geographic factors in Guangdong province, China. Journal of Geographical Sciences, 29(2), 213-230. https://doi.org/10.1007/s11442-019-1593-2.

Zambon, I., Serra, P., Sauri, D., Carlucci, M. \& Salvati, L. (2017). Beyond the 'Mediterranean city': Socioeconomic disparities and urban sprawl in three Southern European cities. Geografiska Annaler: Series B, Human Geography, 99(3), 319-337. https://doi.org/10.1080/04353684.2017.1294857.

Zheng, S. \& Kahn, M.E. (2008). Land and residential property markets in a booming economy: New evidence from Beijing. Journal of Urban Economics 63(2), 743757. https://doi.org/10.1016/j.jue.2007.04.010.

Zhou, G., He, Y., Tang, C., Yu, T., Xiao, G. \& Zhong, T. (2013). Dynamic mechanism and present situation of rural settlement evolution in China. Journal of Geographical Sciences, 23(3), 513-524. https://doi.org/10.1007/s11442-013-1025-7. 